\title{
Tipik Betonarme Bir Hastane Yapısının Güçlendirilmesinde Betonarme Perde Ve Sürtünmeli Sönümleyici Güçlendirme Alternatiflerinin Karşılaştırılması
}

\author{
Erkan Akpinar ${ }^{*}$, Ahmet Özenir ${ }^{2}$, Sebastian Tebeck Akanji ${ }^{3}$ \\ 1* Kocaeli Üniversitesi, Mühendislik Fakültesi, İnşaat Mühendisliği Bölümü, Kocaeli, Türkiye, (ORCID: 0000-0001-6576-2362), erkan.akpinar@kocaeli.edu.tr \\ ${ }^{2}$ Kocaeli Üniversitesi, Mühendislik Fakültesi, İnşaat Mühendisliği Bölümü, Kocaeli, Türkiye, (ORCID: 0000-0001-6527-8626), ozenir.ahmet@gmail.com \\ ${ }^{3}$ Kocaeli Üniversitesi, Mühendislik Fakültesi, İnşaat Mühendisliği Bölümü, Kocaeli, Türkiye (ORCID: 0000-0002-5299-9181), akanjisebastian@gmail.com
}

(International Conference on Design, Research and Development (RDCONF) 2021 - 15-18 December 2021)

(DOI: $10.31590 /$ ejosat.1042760)

ATIF/REFERENCE: Akpinar, E., Özenir, A. \&Akanji, S. T. (2021). Tipik Betonarme Bir Hastane Yapısının Güçlendirilmesinde Betonarme Perde Ve Sürtünmeli Sönümleyici Güçlendirme Alternatiflerinin Karşılaştırılması. Avrupa Bilim ve Teknoloji Dergisi, (32), 928-939.

\section{$\ddot{O} \mathbf{z}$}

Mevcut yapıların deprem güvenliği, önemi her geçen gün artan bir olgudur. Eski ve güncelliğini yitirmiş yönetmeliklere göre tasarlanıp inşa edilmiş yapıların yıkılıp yeniden yapılması, büyük çoğunluk tarafından ilk başta akla gelen çözüm gibi algılansa da güçlendirme uygulamaları, daha akılcı ve makul bir seçenek olarak masada yer almaktadır. Mevcut betonarme binalarının deprem dayanımını iyileştirmek için birçok güçlendirme yöntemi bulunmaktadır. Özellikle global dayanım ve deplasman sorunu bulunan betonarme yapıların güçlendirilmesinde en klasik ve bilindik olan ancak en çok zaman alan ve yapı kullanımını uzun süre engelleyen yöntem, perde duvar eklenerek güçlendirme yapılmasıdır. Modern alternatifler, benzer sorun yaşayan betonarme binalardaki güçlendirme uygulamalarında hem zaman hem de kolaylık açısından öne çıkmaktadır. Yapılarda pasif davranış kontrolü sağlayan sürtünmeli sönümleyicilerin eklenmesi, bu modern güçlendirme yöntemlerinden birisidir. Sürtünmeli sönümleyicilerin enerji yutma kapasiteleri sayesinde hem deprem yükünde oluşacak taban kesme kuvveti sınırlı seviyede tutulabilmekte hem de mevcut elemanlar üzerinde doğrusal elastik olmayan deformasyon talepleri azalmaktadır. Bu çalışmada, 1975 Türkiye Deprem Yönetmeliğine göre tasarlanmış ve inşa edilmiş yetersiz deprem performansına sahip mevcut bir hastane binasının, iki farklı yöntemle güçlendirilmesi değerlendirilmiş ve doğrusal olmayan statik itme ve dinamik analizlerle elde edilen sonuçlar değerlendirilmiştir. Çalışmada güçlendirme alternatifi olarak konvansiyonel betonarme perde duvar ilavesi ve modern sürtünmeli sönümleyici ilavesi alternatifleri, ayrı ayrı olarak uygulanmış ve sonuçları karşılaştırılmıştır. Çalışma kapsamında mevcut durumun, perde duvarlarla güçlendirilmiş durumun ve sürtünmeli sönümleyicilerle gülendirilmiş durumun deprem performansları belirlenerek kıyaslanmıştır. Sonuçlara göre her iki yöntem ile bina tepe deplasman talepleri, göreli kat ötelemeleri ve eleman hasar durumlarında önemli ölçüde iyileşmeler olmuştur. Buna karşın sürtünmeli sönümleyiciler ile yapılan güçlendirmede, kat kesme kuvvetlerinin daha düşük seviyelerde kaldığı belirlenmiştir.

Anahtar Kelimeler: Betonarme Yapılar, Güçlendirme, Sürtünmeli Sönümleyiciler, Doğrusal Olmayan İtme Analizi, Zaman Tanım Alanında Doğrusal Olmayan Analiz

\footnotetext{
*Sorumlu Yazar: erkan.akpinar@kocaeli.edu.tr
} 


\title{
Comparison Of Reinforced Concrete Shear Wall And Friction Damper Retrofitting Alternatives For Reinforcement Of A Typical Reinforced Concrete Hospital Building.
}

\begin{abstract}
Earthquake safety of existing structures is a phenomenon whose importance is increasing day by day. Although demolition and rebuilding of structures designed and built according to old and outdated codes is perceived as the first solution that comes to mind by the vast majority, retrofitting applications emerge as a more rational and reasonable option. There are many strengthening methods to improve the earthquake resistance of existing reinforced concrete buildings. The most classical and well-known method, at the same time the most time-consuming and long-lasting method for strengthening reinforced concrete structures, especially those with global strength and displacement problems, is the reinforcement by adding shear walls. Modern alternatives stand out in terms of both time and convenience in reinforcement applications in reinforced concrete buildings that have similar problems. The addition of friction dampers that provide passive behavior control in structures is one of these modern strengthening methods. Thanks to the energy absorption capacity of the friction dampers, the base shear forces that occur under earthquake excitations can be kept at a limited level and the non-linear inelastic deformation demands on the existing elements can be drastically reduced. In this study, the reinforcement of an existing hospital building with insufficient earthquake performance, which was designed and built according to the 1975 Turkish Earthquake Code, was evaluated by two different methods and the results obtained by nonlinear static pushover and dynamic analyses were evaluated. In the present study, addion of conventional reinforced concrete shear walls and modern friction damper were applied separately as reinforcement alternatives and their results were compared. Within the scope of this study, the earthquake performances of the current state of the structure, the shear wall-reinforced state and the friction dampers-reinforced state were determined and compared. According to the results, there were significant improvements in building top displacement demands, interstory drifts and element damage conditions with both methods. On the other hand, it was determined that the floor shear forces remained at lower levels in the reinforcement with friction dampers.
\end{abstract}

Keywords: Reinforced Concrete Structures, Retrofitting, Frictional Dampers, Nonlinear Pushover Analysis, Nonlinear Time History Analysis.

\section{Giriş}

Son yüzyıl içerisinde Türkiye'de birçok yıkıcı deprem meydana gelmiştir ve buna bağlı olarak günümüze kadar deprem yönetmeliklerinin yenilenmesine ihtiyaç duyulmaktadır. 27 Aralık 1939 M7.9 büyüklügündeki Erzincan depreminden sonra deprem yönetmeliği anlamında ilk çalışma yürütülmüştür (Duyguluer, 1997). Türkiye'de ilk deprem yönetmeliği 1940 yılında yayınlanmış ve bu yönetmelikte deprem bölgesinden bağımsız olarak bina ağırlığının \%10'u kadar bir yatay kuvvetin bina yüksekliği boyunca üniform olarak binaya etki ettiği kabul edilmiştir. Söz konusu yönetmelik zaman içerisinde birçok kez güncellenmiş ve günümüzde kullanılan modern analiz yöntemleri olan doğrusal mod birleştirme yöntemi ve doğrusal olmayan zaman tanım alanında analiz yöntemi, ilk kez 1997 yılındaki deprem yönetmeliğinde kapsama dahil edilmiştir (ABYYHY, 1997). Yine 1997 yılındaki revizyonda, modern tasarım spektrumu ve kapasite tasarım ilkeleri tanımlanmış olup, deprem yükü azaltma katsayıları taşıyıcı sistem tipine göre ayrı ayrı belirtilmiştir. 2007 deprem yönetmeliğinde eklenen en önemli yeni bölüm ise mevcut binaların deprem performansının belirlenmesi ve güçlendirilmesini kapsayan bölümdür (DBYBHY, 2007). Deprem ynetmeliğinde en son ve tarihteki en kapsamlı revizyon, 2018 yılında gerçekleştirilmiştir. Bu revizyonda, deprem etkisi tanımına yeni bir bakış açısı getirilmiş, şekil değiştirmeye dayalı tasarım yaklaşımı ve performansa dayalı tasarım kavramları eklenmiştir. Bunun dışında önemli sayılabilecek yenilikler olarak, tasarım gözetmenliği kavramı, taşıyıcı olmayan elemanların değerlendirilmesi, taban yalıtımlı bina tasarımı ve yüksek yapı tasarımı sayılabilir (TBDY, 2018).

Şiddetli depremler altında yapılar aşırı deprem enerjisine maruz kalırlar ve bu yapıların belirli elemanları elastik olmayan deformasyonlar yapılarak bu enerjiyi tüketirler. $\mathrm{Bu}$ durum yapıdaki taşıyıcı elemanlar ağır hasarlar görebilmekte ve yapının kullanılamaz haline gelmesine sebep olabilmektedir (Symans ve değ., 2008).

Kuzey Amerika ve Japonya'da geliştirilen özel yapı kontrol sistemleri, yapı elemanlarında meydana gelecek hasarın kontrol altına alınmasını ve azaltılmasını sağlamaktadır. $\mathrm{Bu}$ gibi yaklaşımlarla yapının dinamik özellikleri değiştirilerek, yapısal elemanlardaki elastik olmayan deformasyon talebinin azaltıması sağlanmaktadır. Günümüzde bu yaklaşımı sağlayan en pratik ve güvenilir sistemler, "Pasif Kontrol Sistemleri" olarak ön plana çıkmaktadır (Pall, 2004). Bu sistemler ikiye ayrılabilir: taban yalıtımı ve pasif enerji sönümleyici sistemler (ASCE 41-16). Pasif enerji sönümleyici sistemler, sönümleyici elemanların mevcut yapı elemanlarına, planlı bir şekilde yerleştirilmesiyle uygulanırlar ve sisteme giren deprem enerjisinin bu elemanlar tarafından tüketilerek, yapısal elemanların daha az hasar görmesini sağlamaktadırlar.

Günümüzdeki uygulamalarda, viskoz sönümleyiciler, viskoelastik sönümleyiciler, histeretik sönümleyiciler ve sürtünme esaslı sönümleyiciler gibi sistemler en çok kullanılan pasif enerji sönümleyiciler arasında yer almaktadırlar (Aieken, 
$m \ddot{x}+c \dot{x}+k x+\Gamma x=-(m+\bar{m}) \ddot{x}_{g} \quad 1996 ;$ Perry ve diğ., 1993; Soong ve Spencer, 2002; Soong ve Constantinou, 1994). Bu çalışma kapsamında sürtünme esaslı sönümleyiciler dikkate alınmıştır.

$\mathrm{Bu}$ çalışma, modern deprem yönetmeliklerde verilen hükümlere göre yetersiz deprem performansına sahip bir kamu binasının, geleneksel ve modern güçlendirme yöntemleri ile deprem performansının iyileştirilmesini, söz konusu uyugulamaların sonuçlarının kıyaslanmasını kapsamaktadır. Elde edilen sonuçlar değerlendirilerek birbirleriyle karşılaştırılmıştır. Geleneksel güçlendirme yöntemi olarak taşıyıcı sisteme betonarme perde elemanlar eklenmesi yöntemi seçilmiş ve bu yöntemle sistemin yatay yük taşıma kapasitesi ve rijitliği arttırılmıştır. Modern güçlendirme yöntemi olarak ise sürtünme sönümleyici elemanlar sisteme eklenmiş ve mevcut taşıyıcı elemanlar üzerindeki hasar seviyesi azaltılması amaçlanmıştır. Ayrıca bu yöntemle sisteme ilave rijitlik ve yatay yük taşıma kapasitesi sağlanması hedeflenmiştir.

\section{Materyal ve Metot}

\subsection{Genel Prensipler}

Bu bölümde tek serbestlik dereceli sistemlerde, pasif kontrol sisteminin etkileri incelenmiştir. Yapının dinamik davranışını anlamak üzere tek serbestlik dereceli sistemler çoğu zaman yetersiz kalmaktadır. Bu nedenle pasif kontrol sistemlerini içeren çok serbestlik dereceli sistemler de açıklanmaya çalışılmıştır.

Denklem 2.1'de zamana bağlı f(t) dış yüküne maruz kalan tek serbestlik dereceli bir sistem için hareket denklemi verilmiştir (şekil 2.1). Bu denklemde yer alan $\mathrm{m}$, $\mathrm{k}$ ve c ifadeleri sırasıyla kütle, elastik rijitliği, lineer viskoz sönümü göstermektedir.

$\mathrm{f}(\mathrm{t})$ dış yükünün bir deprem etkisi olması durumunda, denklem 2.2 'de gösterilen ifade edilir.

$$
f(t)=-m \ddot{x}_{g}(t)
$$

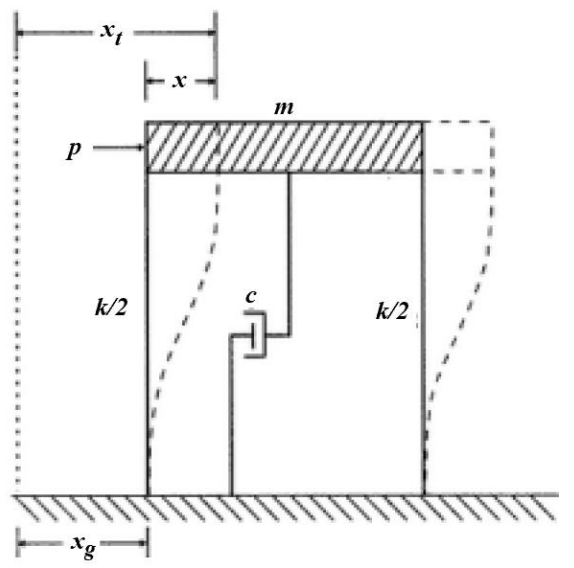

Şekil 2.1: Tek Serbestlik Dereceli Sistem Modeli

Denklem 2.1'de tanımlanan tek serbestlik dereceli sisteme pasif kontrol sistem eklendiğinde, söz konusu durum Şekil 2.2'de gösterildiği gibi ifade edilebilir ve sönümleyiciye ait ilgili terimlerin ilave edilmesiyle Denklem 2.3 elde edilir.

Bu denklemde $\Gamma$ ile pasif control (sönüm) elemanına ait jenerik büyüklük, $\ddot{m}$ ile kontrol elemanın kütlesi ifade edilmektedir.

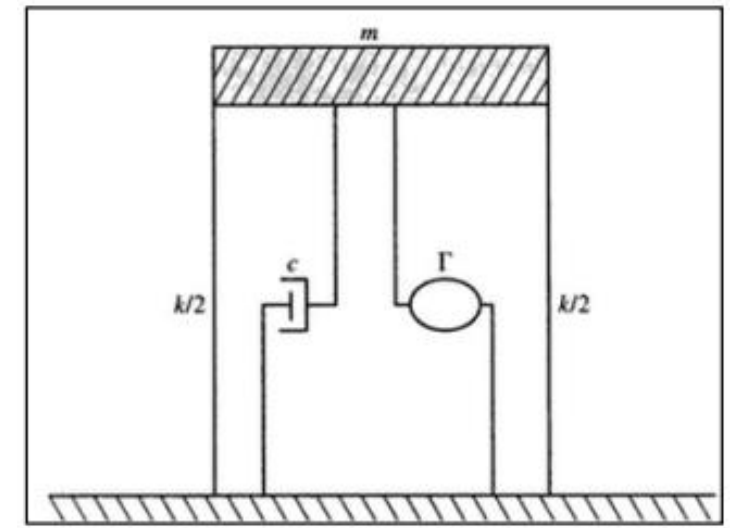

Şekil 2.2: Kontrol elemanın tek serbestlik dereceli sistem modelinde temsil edilmesi

Denklem 2.3'ün çözülmesi için $\Gamma$ 'nin özelliklerinin bilinmesi gerekmektedir ve bu özellik kontrol sisteminin çalışma mekanizmasına bağlı olarak değişmektedir. Pasif kontrol sistemleri için bu özellik yük-deplasman ilişkisi ile ifade edilebilmektedir (Şekil 2.3).

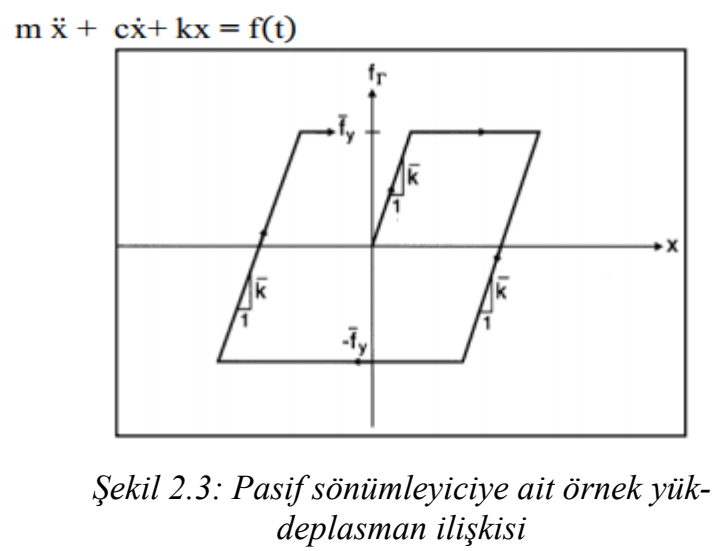

Bu konu üzerinde daha önce yapılan bir çalışmaya göre $\xi=$ 0.05 viskoz sönüm oranına sahip bir yapıya, kütlesi bulunmayan metalik bir pasif sönümleyici eleman eklenmiştir. Sönümleyici elemanın yük-deplasman ilişkisi Şekil 2.3'te verilen yükdeplasman grafiğine benzer olup, $\mathrm{f}_{\mathrm{y}}$ değeri, uygulanan deprem kaydının (1940 El Centro S00E) en büyük yer ivmesi değerinin 20\%'si olarak belirlenmiştir (Soong ve Dargush, 1999). Sönümleyici bulunmayan ve sönümleyici içeren tek serbestlik dereceli sistemler için elde edilen ivme-zaman ve deplasmanzaman geçmişleri Şekil 2.4. ve 2.5 'te verilmiştir. 
Elde edilen sonuçlara göre her iki sistemin davranışları oldukça farklı olup, sistemin ulaştığı en büyük deplasman ve ivme değerlerinde belirgin düşüşler söz konusudur.

Sistemdeki sönümleyici eleman davranışının gerçekçi bir $\mathrm{P}=\mu \mathrm{N}$ sgn(ù) ş̧ekilde elde edilebilmesi için, sistemin zamana bağlı maruz kaldığ 1 yük etkisi altınde uygun şekilde modellenmesi gerekmektedir. Bunu için sonlu elemanlar yöntemi ile sistem idealize edilerek çok serbestlik dereceli olarak gerçeğe yakın bir şekilde temsil edilmelidir (Denklem 2.4).

$\mathrm{Bu}$ ifadede, $[\mathrm{M}]$ kütle matrisini, $[\mathrm{C}]$ sönüm matrisini, $[\mathrm{K}]$ rijitlik matrisini ve $[\Gamma]$ ise sönüm elemanlarını temsil eden operatörü göstermektedir.
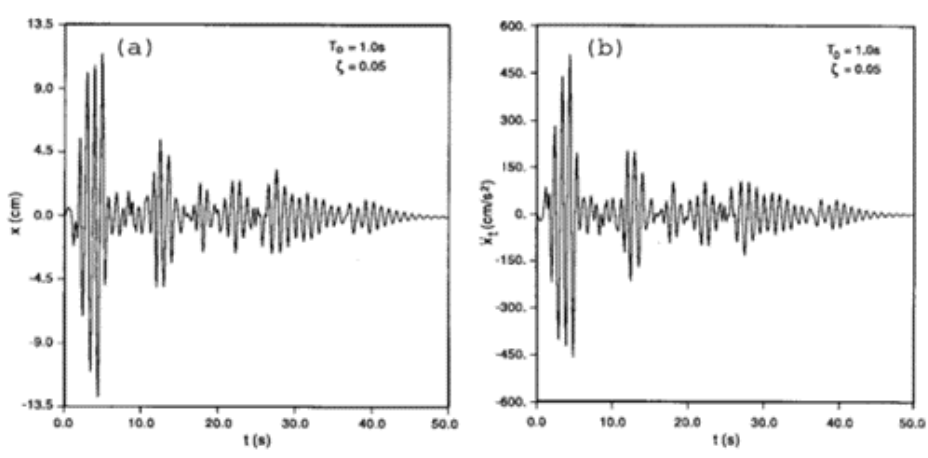

Şekil 2.4: Sönümleyicisiz TSD sisteme ait tepkiler a) DeplasmanZaman, b) İvme-zaman geçmişi (Soong ve Dargush, 1999)
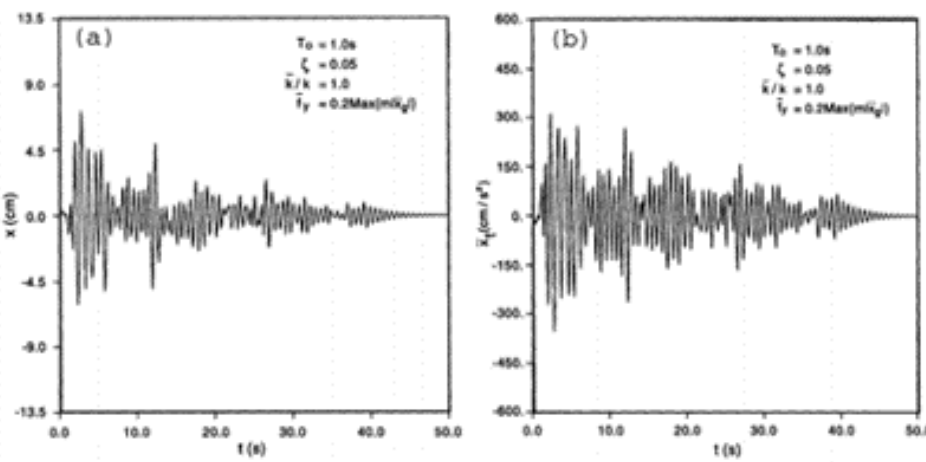

Şekil 2.5: Sönümleyicili TSD sisteme ait tepkiler a) DeplasmanZaman, b) İvme-zaman geçmişi (Soong ve Dargush, 1999)

\subsection{Sürtünme Esaslı Sönümleyiciler}

Sürtünme esaslı sönümleyiciler, iki katı cismin birbirlerine göre rölatif hareketi sırasında temas yüzeylerinde meydana gelen sürtünme ile enerji tüketirler. Örneğin, oval delikli-bulonlu tip sürtünme sönümleyicilerde, çelik plakaların öngerme kuvveti verilerek birbirlerine bulonlanması ile meydana gelmektedir. Verilen öngerme kuvveti ile önceden belirlenen statik sürtünme kuvveti değerinin aşılmasından sonra çelik plakalar birbirlerine göre rölatif olarak kayarlar. Temas yüzeylerinde meydana gelen kayma hareketi sırasında oluşan sürtünme kuvvetinin ve kayma deformasyon kapasitesinin, stabil bir şekilde korunması amacıyla farklı yüzey malzemeleri kullanılmaktadır.
Pall ve Marsh tarafından yapılan deneysel çalışmalarda, sürtünme sönümleyicilerin davranışının Coulomb sürtünme modeli ile basit bir şekilde temsil edilebileceği görülmüştür (Denklem 2.5).

$\mathrm{Bu}$ ifadede $\mu$ sürtünme katsayısını, $\mathrm{N}$ normal kuvveti ve ư ise hızı göstermektedir.

Coulomb modeline göre normal kuvvet ve sürtünme katsayısı $[\mathrm{M}] \ddot{\mathrm{x}}+[\mathrm{C}] \dot{\mathrm{x}}+[\mathrm{K}] \mathrm{x}+[\Gamma] \mathrm{x}=-([\mathrm{M}]+[\overline{\mathrm{M}}]) \ddot{\mathrm{x}}_{\mathrm{g}} \quad$ zamandan bağımsız olarak sabit

kalmaktadır. Ancak, pratikte bu durumun geçerli olması oldukça zordur ve bu yüzden sönümleyici elemandaki sürtünme kuvveti değiş̧ebilmektedir. Bu durum tasarım sırasında diğer yapısal parametreler gibi göz önüne alınmaktadır.

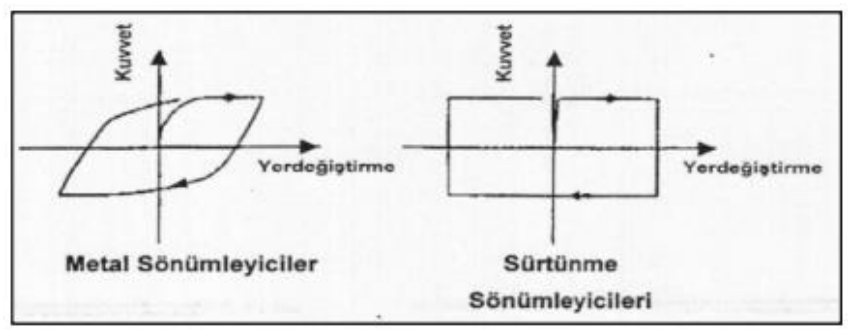

Şekil 2.6: Deplasman duyarl sönümleyicilerin yükdeformasyon grafikleri a) Metalik sönümleyiciler, b) Sürtünme sönümleyiciler

Sürtünme esaslı sönümleyicilerin, tersinir ve tekrarlı yükler altında yük-deformasyon ilişkisi simetriktir. Şekil 2.6'da görüldüğü üzere sürtünmeli sönümleyicilerin yük-deformasyon eğrileri ideal durumda dikdörtgen şekline benzemekte olup, her bir çevrimde önemli miktarda enerji yutarlar. Özellikle diğer pasif sönümleyiciler ile karş̧laştırıldığında, sürtünmeli sönümleyiciler ile daha efektif çözümler elde edilebilmektedir. Ancak, yükdeformasyon eğrisinin dikdörtgen şekline benzemesi, davranışının büyük ölçüde doğrusal olmayan tipte olduğunu göstermektedir. Sönümleyiciler, taşıyıcı sisteme ilave rijitlik katarlar ve sönümleyicilerin yük kapasitesi aşılana kadar taşıyıcı sistemde oluşacak deformasyonların sınırlı düzeyde kalmasını sağlarlar.

\subsubsection{Sürtünme Teorisi}

Sürtünme ile ilgili ilk bilimsel çalışmalar Da Vinci, Amontons, ve Coulomb'un çalışmalarına kadar uzanır. Şekil 2.7 'de, düz bir yüzey üzerinde yatay olarak hareket eden bir cisim üzerinde oluşan kuvvetler gösterilmiştir. Buna göre $\mathrm{W}$ cismin ağırlığını, F kayma yüzeyi arasında oluşan sürtünme kuvvetini, $\mathrm{N}$ normal kuvveti $(\mathrm{N}=\mathrm{W})$ ve P'de cisme uygulanan kuvveti göstermektedir. Sürtünme kuvveti F, daima cismin hareketine ters yönde oluşmakta olup, statik sürtünme kuvveti $\mathrm{P}$ kuvvetinin artmasına bağlı olarak artmaktadır. Statik sürtünme kuvveti, dengeyi meydana getiren minimum sürtünme kuvveti olup cismin hareketini önlemektedir. Kayma hareketi başlar başlamaz F 
kuvveti sabit kalırken, kinetik sürtünme kuvveti değişmektedir. Ancak, teorik olarak basitleştirme adına sabit olduğu kabul edilir.

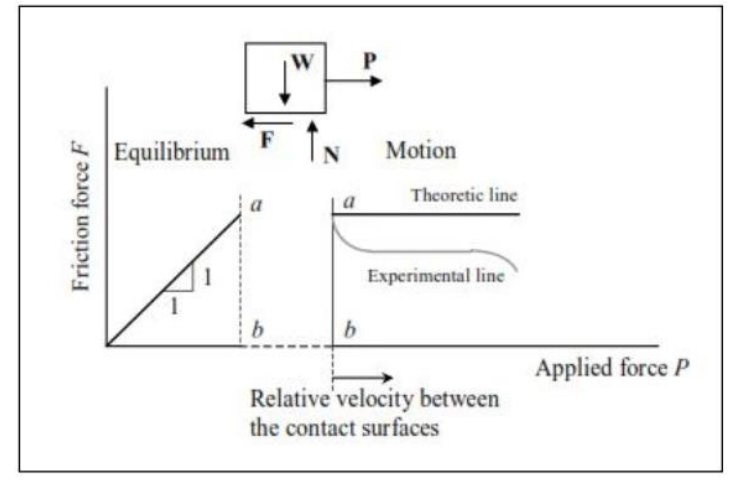

Şekil 2.7: Sürtünme kuvveti-yük ilişkisi

Sürtünme teorisinde fiziksel deney ve gözlemlerden elde edilen basit hipotezlere göre, maksimum sürtünme kuvveti hem normal kuvvetle doğru orantılıdır hem de maksimum kinetik sürtünme kuvvetinden büyüktür. Ayrıca sürtünme kuvveti düşük hızda gerçekleşen kayma hareketi durumunda hızdan bağımsızdır.

\subsection{Sürtünme Sönümleyicilerin Analiz ve Tasarımı}

1989'daki Loma Prieta depreminden sonra binaların ağır hasar görmesi ve bu sistemleri üreten firmaların çoğalmasının önemli etkisiyle, pasif sönümleyiciler için klavuz dökümanlar oluşturulmaya başlanmıştır. Bu bölümde pasif sönümleyicilerin analiz ve tasarım ilkeleri ve FEMA-356 ve ASCE41-06 standartları 1şı̆̆ında kısa bilgiler sunulmuştur.

Bu dökümanlarda pasif sönümleyici sistemler, deplasman ve hız duyarlı olmak üzere iki kategoriye ayrılmışlardır. Deplasman duyarlı sistemlerde yük-deformasyon ilişkisi, sönümleyicinin her iki ucu arasındaki rölatif yer değiştirmenin bir fonksiyonudur ve rölatif hız veya yer hareketinin frekans içeriğinden bağımsızdır. Hız duyarlı sistemlerde ise söz konusu ilişki rölatif hız ve yer hareketinin frekans içeriğinden etkilenmektedir. Tablo 2.1'de ASCE41-06'da yer alan pasif sönümleyici sistemlerin, hedef performans düzeylerine göre etkinliğini gösteren tablo verilmiştir. ASCE41-06 standartında, sönümleyicilerin yapısal analizi için analiz yöntemlerinin kullanımı ile ilgili birçok koşul ve öneriler verilmiştir.

Tablo 2.1. ASCE41-06 Enerji sönümleyiciler

\begin{tabular}{|c|c|c|c|}
\hline \multicolumn{4}{|c|}{$\begin{array}{c}\text { Sismik izolasyon ve Enerji Sönümleyicilerin } \\
\text { Uygulanabilirliği (ASCE41-06) }\end{array}$} \\
\hline $\begin{array}{l}\text { Performans } \\
\text { Seviyesi }\end{array}$ & $\begin{array}{c}\text { Performans } \\
\text { Aralığı }\end{array}$ & $\begin{array}{c}\text { Sismik } \\
\text { Izolasyon }\end{array}$ & $\begin{array}{c}\text { Enerji } \\
\text { Sönümleyiciler }\end{array}$ \\
\hline $\begin{array}{l}\text { Minimum } \\
\text { Hasar }\end{array}$ & \multirow{2}{*}{$\begin{array}{c}\text { Hasar } \\
\text { Kontrol }\end{array}$} & $\begin{array}{l}\text { Oldukça } \\
\text { Etkin }\end{array}$ & Sinirlı \\
\hline $\begin{array}{c}\text { Hemen } \\
\text { Kullanım }\end{array}$ & & Etkin & Etkin \\
\hline $\begin{array}{c}\text { Can } \\
\text { Güvenliği }\end{array}$ & \multirow{2}{*}{$\begin{array}{c}\text { Can } \\
\text { Güvenliğinin } \\
\text { Sağlanması }\end{array}$} & Sinırlı & Etkin \\
\hline $\begin{array}{l}\text { Gömenin } \\
\text { Önlenmesi }\end{array}$ & & $\begin{array}{r}\text { Pratik } \\
\text { Değil }\end{array}$ & Sinırlı \\
\hline
\end{tabular}

\subsection{Doğrusal Olmayan Hesap Yöntemleri}

$\mathrm{Bu}$ çalışmada doğrusal elastik olmayan artımsal eşdeğer deprem yükü yöntemi ve zaman tanım alanında hesap yöntemi olmak üzere yönetmeliklerde geçerli iki doğrusal olmayan hesap yöntemi dikkate alınmıştır.

\subsubsection{Doğrusal Elastik Olmayan Artımsal Eşdeğer Deprem Yükü Yöntemi}

$\mathrm{Bu}$ yöntemde, hakim titreşim mod şekli ile orantılı olacak şekilde, deprem istem sınırına kadar monotonik olarak adım adım arttırılan eşdeğer deprem yüklerinin etkisi altında, doğrusal olmayan itme analizi gerçekleştirilir. Artımsal itme analizinden önce, kütleler ile uyumlu, düşey yüklerin göz önüne alındığı bir doğrusal olmayan statik analiz yapılır. $\mathrm{Bu}$ analizin sonuçları, artımsal itme analizinin başlangıç koşullarını oluşturur. Düşey yük analizini izleyen itme analizinin her bir adımında taşıyıcı sistemde meydana gelen yerdeğiştirme, plastik şekildeğiştirme ve iç kuvvet artımları ile bunlara ait kümülatif değerler ve son adımda deprem istemine karşı gelen maksimum değerler hesaplanır.

Hakim mod şekli ile uyumlu ve sabit yük dağılımına göre yapılan itme analizi ile koordinatları " tepe yerdeğiştirmesi taban kesme kuvveti” olan itme eğrisi elde edilir (Şekil 2.8).

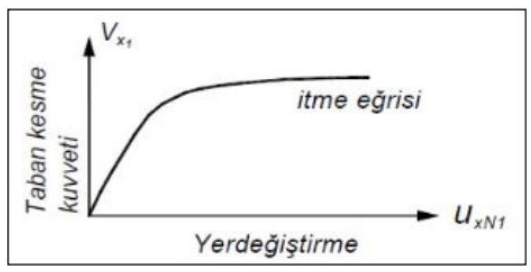

Şekil 2.8. İtme ĕgrisi

Yönetmeliklerde verilen bağlantılarla Şekil 2.8'de uygulanan itme eğrisi koordinatları "modal yerdeğiştirme - modal ivme" olan modal kapasite diyagramına dönüştürülür. Daha sonra modal kapasite diyagramı ile birlikte, depremin talebini ifade eden elastik davranış spektrumu uygun koordinat dönüşümleri yapılarak, aynı eksen takımına çevrilir ve hakim moda ait maksimum modal yerdeğiştirme istemi elde edilir.

$\mathrm{Bu}$ yöntem genellikle, zaman tanım alanında doğrusal olmayan hesap yöntemini uygulamadan önce doğrusal olmayan analiz modellerini doğrulamak için ve yapıyı değerlendirerek doğrusal olmayan davranışını anlamak için kullanılır. Modern yönetmeliklerde birinci modu hakim olan az katlı yapıların analizi için kullanılabildiği belirtilmektedir.

\subsubsection{Zaman Tanım Alanında Doğrusal Olmayan Hesap Yöntemi}

Zaman tanım alanında doğrusal olmayan hesap yöntemi ile belirli sayıdaki kuvvetli yer hareketi kayıdı ölçeklenip tasarım spektrumu ile uyumlu hale getirilir ve yapı bu etkilere maruz 
bırakılır. Taşıyıcı sistemdeki doğrusal olmayan davranış göz önüne alınarak sistemin hareket denklemi adım adım entegre edilir ve her bir zaman artımında sistemde meydana gelen yerdeğiştirme ve iç kuvvetler ile bu büyüklüklerin deprem istemine karşı gelen maksimum veya ortalama değerleri hesaplanır.

Zaman tanım alanında gerçekleştirilecek doğrusal olmayan analizlerde hareket denklemi, yükleme ve tepki geçmişlerinin çok küçük zaman aralıklarına bölünerek birçok farklı yöntem ile adım adım çözülebilir (Hilber ve Hughes, 1998; Clough ve Penzien, 1995).

Günümüzdeki yönetmeliklerde deprem kayıtları geçmiş depremlerde kaydedilmiş kayıtları veya benzeştirilmiş yer hareketleri kullanılabildiği belirtilmektedir. Ancak kadedilmiş yer hareketi kayıtları, yer hareketinin genliği, süresi, faz özellikleri ve frekans içeriği hakkında gerçek bilgileri içerdikleri için büyük avantaj sağlarlar (Fahjan, 2008).

Bu yöntem, doğrusal olmayan artımsal yöntemine göre daha hassas analiz sonuçları veririr. Bunun nedeni yöntemin, çok modlu davranış, zamana bağlı etkiler ve çevrimsel davranışları yakalayabilmesidir.

\subsection{Analitik Çalışma}

$\mathrm{Bu}$ çalışmada gerçekleştirilen analizde dikkate alınan mevcut bina T.C. Sağlık Bakanlığı'nın geçmiş dönemlerde sıklıkla kullandığ 50 yataklı tip hastane projelerinden birisidir. Binanın özellikleri Tablo 2.2'de yer almaktadır.

Tablo 2.2'de verilen bina ve eleman bilgilerine göre SAP2000 yazılımı ile binanın sonlu eleman modeli oluşturulmuştur. $\mathrm{Bu}$ modelde kolon ve kirişler çubuk elemanlar ile döşemeler ise membran elemanlar ile modellenmiştir. Kat döşemeleri rijit diyafram olarak idealleştirilmiştir. Şekil 2.9'da bina modeline ait görünüşler verilmiştir.
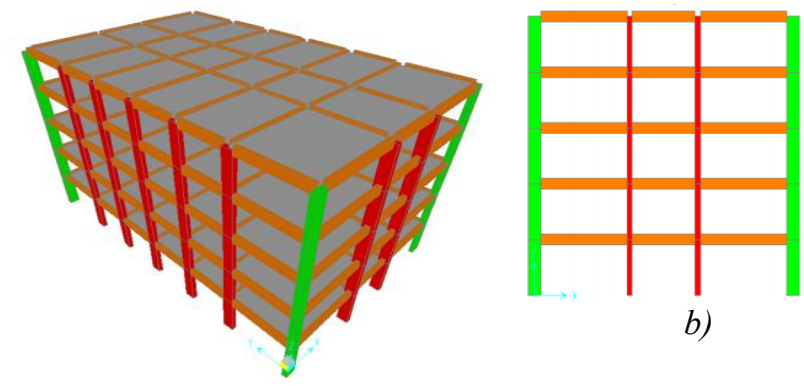

b)

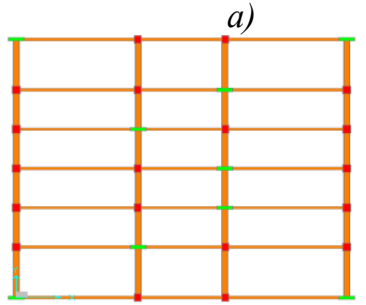

c)
Şekil 2.9. a) Mevcut binanın 3 boyutlu sonlu eleman modeli.

b) Kısa doğrultu en dış aks kesit görünüşü. c) Kat planı. d) Uzun doğrultudaki en dış aks kesit görünüşü

\subsubsection{Kolon ve Kiriș Kesit Analizleri}

Kolon ve kirişler doğrusal elastik olmayan analizlerde kullanılmak üzere, XTRACT yazılımı kullanılarak gerekli kapasiteler belirlenmiştir. (Chadwell, 2002).

Kolonlar için oluşturulan eksenel kuvvet - toplam eğrilik ilişkileri Şekil 2.10'da gösterilmiştir. Kirişler için ise elde edilen moment - eğrilik ilişkileri Şekil 2.11'de yer almaktadır.

Tablo 2.2. Bina özellikleri

\begin{tabular}{|c|c|}
\hline Bina Kat Adedi & 5 \\
\hline Bina Kat Yüksekliği, (m) & 3.0 \\
\hline Bina Kullanım Amacı & Hastane \\
\hline Beton (Tüm Betonarme Elemanlarda) & C18 \\
\hline Donatı Çeliği & $S 420 a$ \\
\hline Bina Kısa Yönü Aks Mesafeleri, (m) & $5.25,3.7,5.25$ \\
\hline Bina Uzun Yönü Aks Mesafeleri, (m) & $\begin{array}{r}4.5,3.5,3.5 \\
3.5,3.5,4.5\end{array}$ \\
\hline Bina Bilgi Düzeyi & Kapsamll \\
\hline Kiriş Boyutlarl, (cm) & $25 \times 60$ \\
\hline Kolon Boyutları, (cm) & $30 \times 70$ \\
\hline Döşeme Kalınlığı, (cm) & 14.0 \\
\hline
\end{tabular}

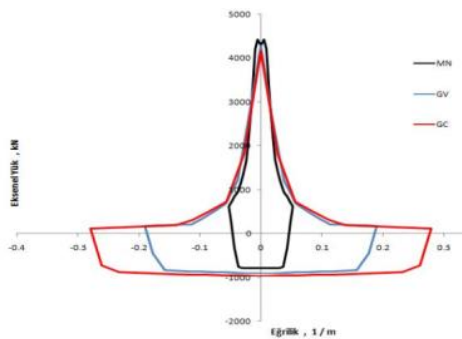

a)

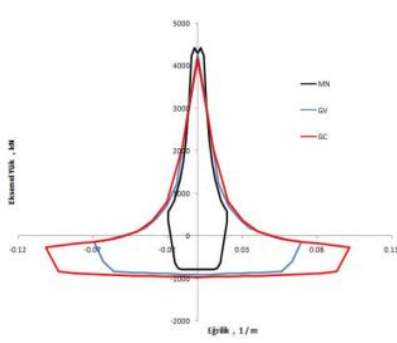

b)
Şekil 2.10. Kolonlar için hasar sınırlarını tanımlayan eksenel kuvvet - eğrilik ilişkileri a) Kolon uzun doğrultusu, b) Kolon kısa doğrultusu için

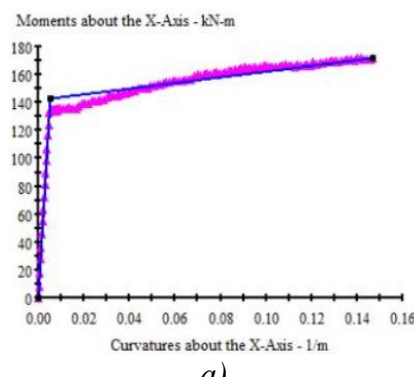

a)

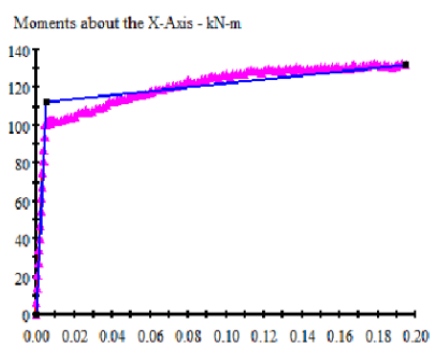

b)
Şekil 2.11. Kirişler için moment - ĕgrilik ilişkileri, a) Negatif moment etkisi, b) Pozitif moment etkisi

\subsubsection{Mevcut Binanın Doğrusal Elastik Olmayan Artımsal Eşdeğer Deprem Yükü Yöntemi ile İtme Analizi}


İtme analizi sonucunda elde edilen spektral yerdeğiştirmeler, hem X hem Y doğrultuları için Şekil 2.12'de verilmiştir. Elde edilen bu spektral yerdeğiştirmeler, eşdeğer tek serbestlik dereceli sistem için modal yerdeğiştirme istemine eşit olup uygun koordinat dönüşümü ile çok serbestlik dereceli sistemin tepe yerdeğiştirme istemine Denklem 2.6 yardımıyla dönüştürülmüştür. Denklem 2.6'ya göre hesaplanan $\mathrm{X}$ ve $\mathrm{Y}$ doğrultuları için bina tepe deplasman istemleri sırasıyla $0.17 \mathrm{~m}$ ve $0.12 \mathrm{~m}$ 'dir. SAP2000 programında, her iki doğrultuda bu tepe yerdeğiştirme istemlerine ulaşıncaya kadar artımsal statik olarak itme işlemi uygulanmıştır. Elde edilen sonuçlar Bölüm 3'te sunulmuştur

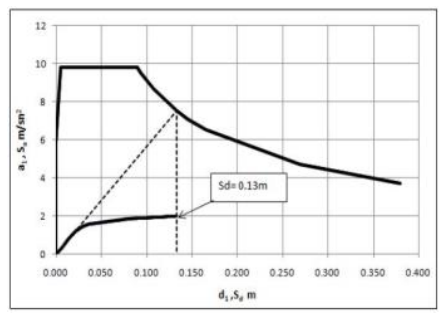

a)

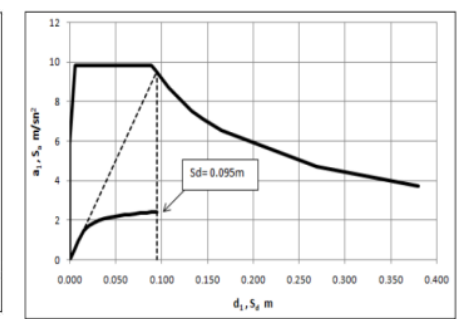

b)

Şekil 2.12. Binanın her iki doğrultusu için modal kapasite diyagramı ve doğrusal olmayan spektral yerdeğiştirme istemi, a) X doğrultusu, b) Y doğrultusu

\subsubsection{Betonarme Perdeler ile Güçlendirilen Binanın Doğrusal Elastik Olmayan Artımsal Eşdeğer Deprem Yükü Yöntemi ile İtme Analizi}

Mevcut binanın her iki doğrultusunda da sisteme ek burulma yükleri getirmeyecek şekilde, betonarme perdeler eklenmiştir. Perdeler mevcut çerçeveler içerisine yerleştirilmiş olup, perde eklenen çerçevelerin kolonları, $15 \mathrm{~cm}$ kalınlığında betonarme manto ile güçlendirilmiştir. Perdelerin kalınlığ $130 \mathrm{~cm}$ olup, beton sınıfı C30, donatı çeliği kalitesi S420a olarak belirlenmiştir.

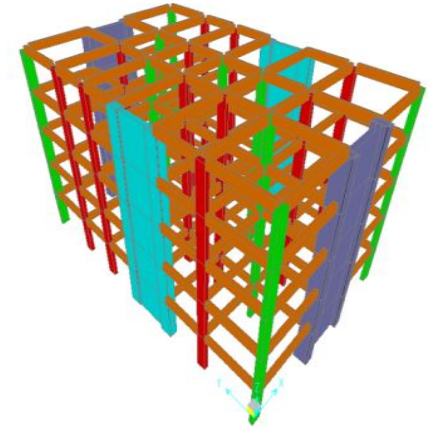

a)

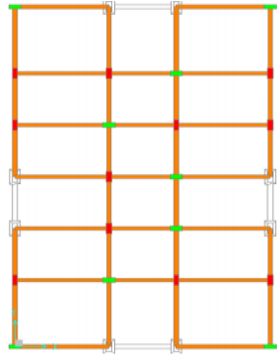

b)

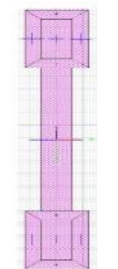

c)

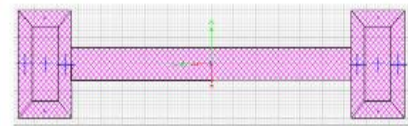

Şekil 2.13. a) Betonarm Perderlele güçlendirilmiş hali. b) Perdelerin kat planında yerleşimi. c) Y doğrultusunda perde kesit görünüşü. d) X doğrultusunda perde kesit görünüşü

Perdeler Sap2000'de çubuk elemanlar ile modellenmiştir. Şekil 2.13'de perdelerin yerleşimi ve perde kesitleri verilmiştir. $u_{\mathrm{xN} 1}^{(p)}=\Phi_{\mathrm{xN} 1} \Gamma_{\mathrm{x} 1} \mathrm{~d}_{1}^{(\mathrm{p})} \quad$ Analiz sonucunda elde edilen doğrusal $\mathrm{u}_{\mathrm{yN} 1}^{(\mathrm{p})}=\Phi_{\mathrm{yN} 1} \Gamma_{\mathrm{x} 1} \mathrm{~d}_{1}^{(\mathrm{p})} \quad \begin{aligned} & \text { olmayan spektral yerdeğiştirme istemi } \\ & \text { Şekil 2.14'de verilmiştir ve bu istemler }\end{aligned}$ modal yerdeğiştirme istemine eşittir. Çok serbestlik dereceli sistemin tepe yerdeğiştirme istemine, Denklem 2.6 yardımıyla dönüşüm yapılarak geçimiş olup, $\mathrm{X}$ ve $\mathrm{Y}$ doğrultuları için sırasıyla $0.066 \mathrm{~m}$ ve $0.060 \mathrm{~m}$ değerleri elde edilmiştir.

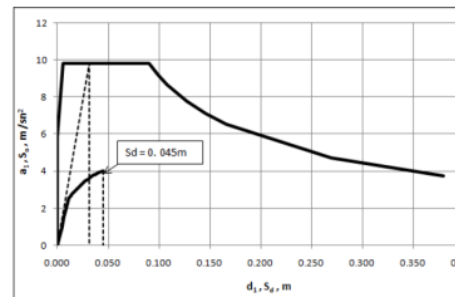

a)

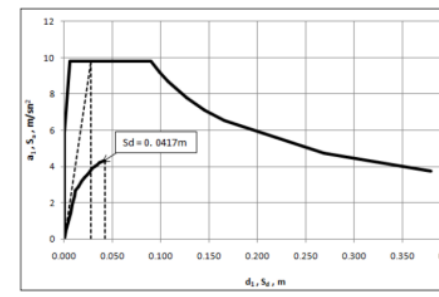

b)
Şekil 2.14. Betonarme perdelerle güçlendirilen binanın her iki doğrultusu için modal kapasite diyagramı ve doğrusal olmayan spektral yerdeğiştirme istemi, a) X doğrultusu, b) $Y$ dogrultusu

\subsubsection{Sürtünme Esaslı Sönümleyiciler ile Güçlendirilen Binanın Doğrusal Elastik Olmayan Artımsal Eşdeğer Deprem Yükü Yöntemi ile İtme Analizi}

Çalışma kapsamında mevcut binanın her iki doğrultusunda da sürtünme sönümleyiciler yerleştirilerek diğer alternatif güçlendirme yöntemi uygulanmış ve performansının iyileştirilmesi hedeflenmiştir. $100 \mathrm{kN}$ ve $150 \mathrm{kN}$ kapasiteli sürtünme sönümleyiciler kullanılmıştır.

Sürtünme esaslı sönümleyiciler, diyagonal çapraz formunda yerleştirilen çelik kutu profiller ile betonarme elemanlara bağlanmıştır. Bu bağlantı elemanları, elastik davranış gösterecek biçimde ve hiçbir durumda elastik ötesi deformasyon meydana gelmeyecek şekilde boyutlandırılmıştır. Söz konusu elemanlar en büyük deprem seviyesi için ayrıca kontrol edilmiştir. 


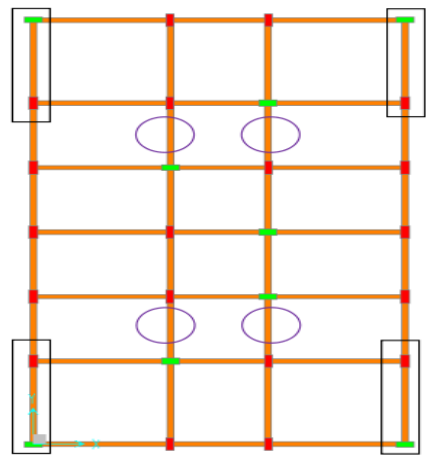

a)

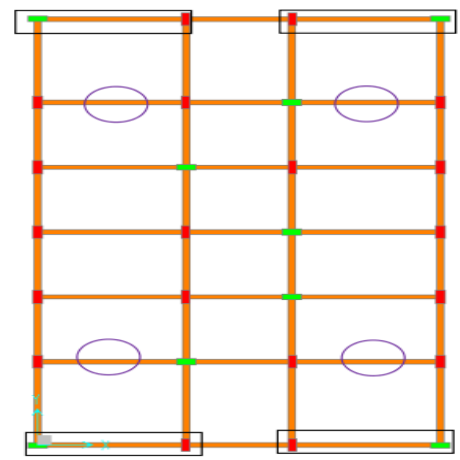

b)
Şekil 2.15. Sürtünme sönümleyicilerin kat planlarında yerleşimi, a) Y doğrultusunda yerleştirilenler, b) $X$ doğrultusunda yerleştirilenler

Şekil 2.15 'de sürtünme esaslı sönümleyici yerleştirilen çerçevelerin planda yerleşimi verilmiştir. Dikdörtgen ile işaretli çerçevelerde tüm katlarda, yuvarlak ile işaretli çerçevelerde ise sadece ilk üç katta sönümleyici yerleştirilmiştir.

Analiz sonucunda elde edilen doğrusal olmayan spektral yerdeğiştirme istemi Şekil 2.16'de verilmiştir ve bu istemler modal yerdeğiştirme istemine eşittir. Çok serbestlik dereceli sistemin tepe yerdeğiştirme istemine, Denlem 2.6 yardımıyla dönüşüm yapılarak geçimiş olup ,X ve $\mathrm{Y}$ doğrultuları için sırasıyla $0.07 \mathrm{~m}$ ve $0.07 \mathrm{~m}$ elde edilmiştir.

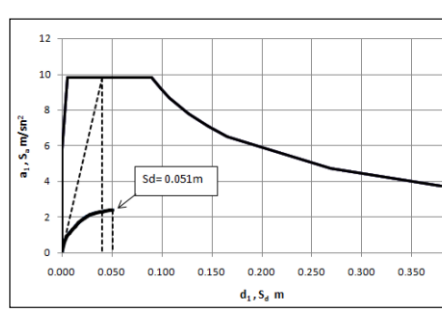

a)

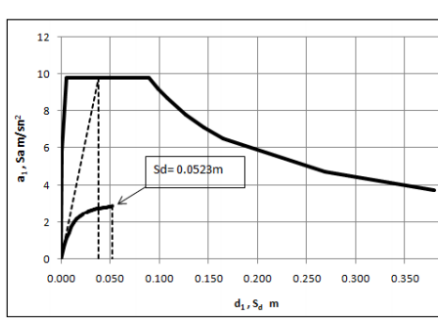

b)
Şekil 2.16. Sürtünme sönümleyicilerle güçlendirilen binanın her iki doğrultusu için modal kapasite diyagramı ve doğrusal olmayan spektral yerdeğiştirme istemi, a) X doğrultusu, b) $Y$ doğrultusu

\subsubsection{Sürtünme Sönümleyiciler ile Güçlendirilen Binanın Zaman Tanım Alanında Doğrusal Elastik Olmayan Yöntem ile Analizi}

Bu çalışmada zaman tanım alanında analiz yöntemi sadece sürtünme sönümleyiciler ile güçlendirilen binalar için uygulanmıştır. Kullanılan kuvvetli yer hareketi seti Pasifik Deprem Mühendisliği Araştırma Merkezi (PEER) veri bankasından alınmıştır. $\mathrm{Bu}$ deprem kayıtları, modern yönetmeliklerde verilen koşullara uygun bir şekilde zaman tanım alanında ölçeklenmiştir. SAP2000 programında bu ölçeklenmiş kayıtlarıla sürtünme sönümleyiciler ile güçlendirilen binanın analizi yapılmıştır.
Doğrusal elastik olmayan artımsal eşdeğer deprem yükü yöntemi ile gerçekleştirilen analizlerden elde edilen sonuçlar mevcut binanın durumu, betonarme perdelerle güçlendirilmiş durum ve sürtünme sönümleyicilerle güçlendirilmiş durum için verilmiştir. Elde edilen sonuçlar, modal kapasite eğrileri, kat kesme kuvvetleri, kat yerdeğiştirmeleri ve göreli kat ötelemeleri açısından karşılaştırılmıştır. Sonrasında sürtünme sönümleyiciler için doğrusal elastik olmayan artımsal eşdeğer deprem yükü yöntemi ve zaman tanım alanında doğrusal elastik olmayan analiz yöntemi için elde edilen sonuçlar yine aynı parametreler açısından karşılaştırılmıştır.

İlk olarak mevcut ve güçlendirilmiş binalar için doğrusal elastik olmayan artımsal eşdeğer deprem yükü yöntemi ile elde edilen modal kapasite eğrileri verilmiştir (Şekil 3.1). Modal kapasite eğrileri, modal yerdeğiştirme istemine kadar elde verilmiştir. Buna göre, sürtünme sönümleyicilerin kullanıldığı durumda sistemin yatay yük taşıma kapasitesinde ve rijitliğinde önemli miktarda artış görülmüştür. Söz konusu iyileşme sönümleyicilerin sürtünme kuvveti kapasitesinden ve kullanılan çelik çaprazların eksenel rijitliğinden kaynaklanmaktadır. Binanın rijitliğindeki artış ve sönüme bağlı olarak, modal yerdeğiştirme isteminde azalma meydana gelmiştir. Perdeler kullanılarak yapılan güçlendirmede de benzer değişimler elde edildiği görülmüştür.

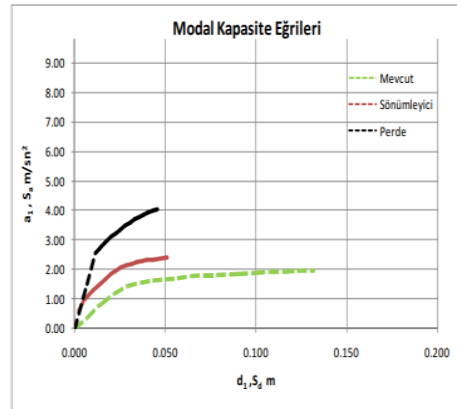

a)

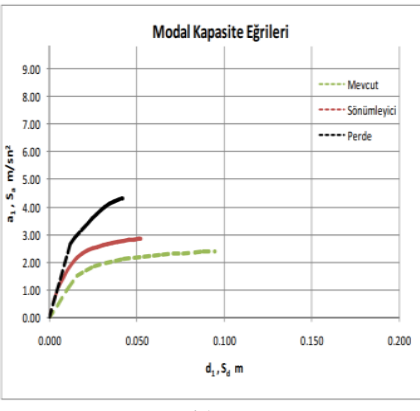

b)
Şekil 3.1. Doğrusal elastik olmayan artımsal eşdeğer deprem yükü yöntemi için elde edilen modal kapasite eğrilerinin karşılaştırılması (ĕ̆riler modal yerdeğiştirme istemine kadar verilmiştir), a) X doğrultusu için, b) Y doğrultusu için

Mevcut ve güçlendirilen binalarda elde edilen kat kesme kuvvetlerinin değişimi Şekil 3.2'de verilmiştir. Buna göre, perdeli sistemde elde edilen kat kesme kuvvetlerinin mevcut ve sönümleyicili duruma göre oldukça fazla olduğu görülmektedir.

\section{Araştırma Sonuçları ve Tartışma}




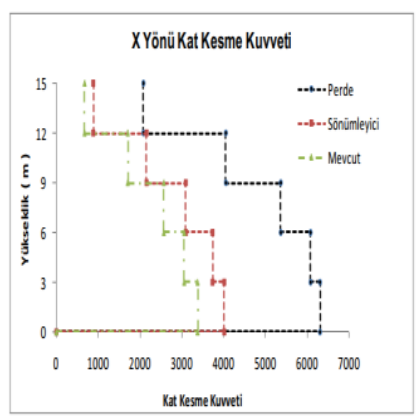

a)

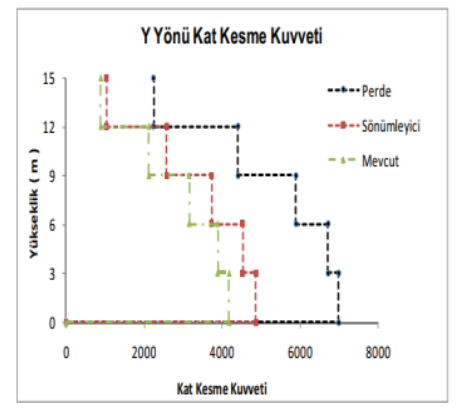

b)
Şekil 3.2. Doğrusal elastik olmayan artımsal eşdeğer deprem yükü yöntemi için elde edilen kat kesme kuvvetlerinin karşılaştırılması, a) X doğrultusu için, b) Y doğrultusu için

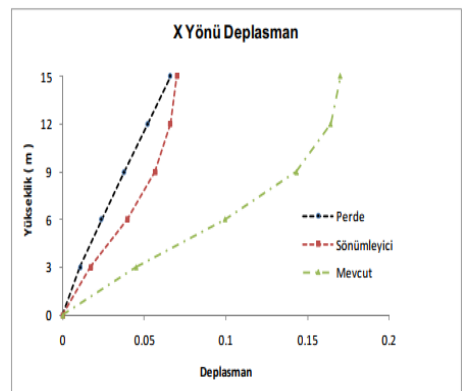

a)

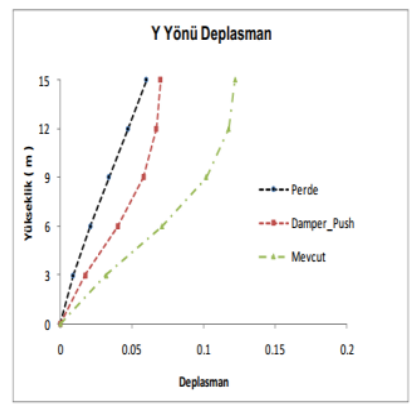

b)
Şekil 3.3. Doğrusal elastik olmayan artımsal eşdeğer deprem yükü yöntemi için elde edilen bina deplasman profillerinin karşılaştırılması, a) X doğrultusu için, b) Y doğrultusu için

Üç farklı durum için deplasman profilleri Şekil 3.3'de yer almaktadır. Buna göre sönümleyicilerin eklenmesi ile birlikte, deplasmanlarda önemli miktarda azalmalar söz konusudur. Perdeli durumda ise binanın deplasman profili çerçeve davranışından çıkıp perdeler tarafından kontrol edilen bir konsol davranışına dönüşmüştür.

Şekil 3.4'de göreli kat ötelemelerinin karşılaştırılması verilmiştir. Şekilde görüldüğü üzere, mevcut durumda 1.katta 0.02 'ye yakın olan bu değer, sönümleyicilerin eklenmesi ile birlikte 0.01 'in altına düşmüştür. Benzer şekilde perdeli durumda ise 0.005 varan bir azalma gerçekleşmiştir. Sistemde meydana gelen hasarın bir göstergesi olarak kabul edilen göreli kat ötelemeleri, sönümleyicilerin eklenmesi durumunda da perde eklenerek yapılan güçlendirme uygulamasında olduğu gibi önemli miktarda azaltılmıştır.

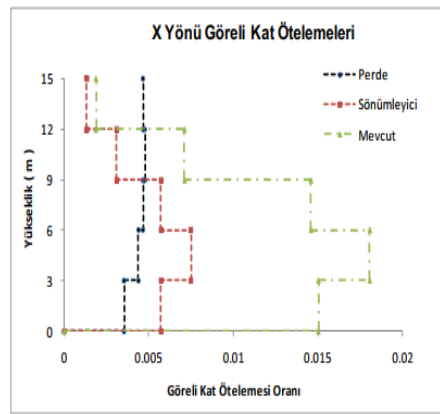

a)

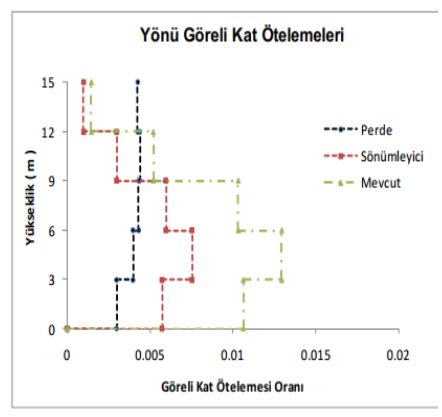

b)

\section{Şekil 3.4. Doğrusal elastik olmayan artımsal eşdeğer deprem yükü yöntemi için elde edilen göreli kat ötelemelerinin karş̧laştırılması, a) X doğrultusu, b) Y doğrultusu}

Mevcut durumda zemin katta, göçme performans seviyesinde kolon hasarı gözlenmiştir. Hem betonarme perdelerle güçlendirme uygulamasında hem de sürtünme esaslı sönümleyicilerle güçlendirme uygulamasında, kolonlardaki söz konusu hasar oluşumu engellenmiş ve yapıdaki tüm kolonların performans seviyesi, hemen kullanım seviyesi olacak şekilde iyileştirilebilmiştir. Mevcut durumun performans incelemesinde, kirişlerde dördüncü kata kadar plastik davranış görüldüğü ancak hasar seviyesinin sınırlı kaldığı belirlenmiştir (belirgin hasar seviyesine geçen kiriş oranları ilk üç katta \%50'ye yakın, dördüncü katta $\% 25$ ' yakın). Perde duvar kullanılarak yapılan güçlendirmede, tüm katlarda bulunan kirişlerdeki hasar miktarı büyük ölçüde sınırlanmış ve plastik davranış gösteren kiriş sayısı önemli ölçüde azalmıştır (belirgin hasar seviyesine geçen kiriş oranları tüm katlarda kirişlerin yaklaşık $\% 5$ seviyesindedir, geriye kalan kirişlerde plastikleşme oluşmamıştır). Sürtünme esaslı sönümleyicilerle yapılan güçlendirmede kirişlerdeki hasar seviyesinde, mevcut duruma göre iyileşme olduğu tespit edilmiş olup, plastik davranış gösteren kirişlerin sadece ilk iki katta yer aldığı belirlenmiştir (belirgin hasar seviyesine geçen kirişler sadece ilk iki katta yer almakta olup, oran \%50 civarındadır). Öte yandan sönümleyicilerin eklendiği durumdaki plastikleşen kirişlerin oranının, perde ile yapılan güçlendirmeye göre daha fazla olduğu görülmüştür. Bu durumun, ilave edilen perdelerin, elastik kalan çapraz bağlantı elemanları ile birlikte sürtünme esaslı sönümleyici takımına göre çok daha yüksek olan rijitliğinden kaynaklandığı ve özellikle ilk iki katta bu durumun farklılığının daha belirgin olduğu anlaşılmaktadır. Söz konusu durum, Şekil 3.4'deki göreli kat ötelemesi karşılaştırmasında da kendisini göstermektedir. Sürtünme esaslı sönümleyicilerin aktivasyon kuvvetleri ve çaprazların dayanımının değiştirilmesi ile kiriş performanslarında da elde edilenden daha iyi performans seviyesine ulaşılabileceği açıktır. Buna rağmen belirtildiği üzere, her iki güçlendirmede de kolonlarda benzer biçimde, tatmin edici bir performans artı̧̧ı elde edilmiş durumdadır. Öte yandan, eklenen ve deprem etkisini büyük oranda üstüne alan betonarme perdelerde de elastik ötesi hasarlar ile karşılaşılacağı, sürtünme esaslı sönümleyici eklenmesi durumunda ise elastik ötesi davranış ve enerji tüketiminin büyük oranda sönümleyicilerde gerçekleşeceği göz ardı edilmemelidir. Şekil 3.2'de görülen kat kesme dağılımları bu durumu açıklamakta olup, perde ilavesi durumunda kat kesme kuvvetlerinin, mevcut duruma ve sürtünme esaslı sönümleyici ile güçlendirme durumuna göre ciddi oranda arttığı görülmektedir.

Sürtünme esaslı sönümleyiciler ile güçlendirilen binanın, doğrusal elastik olmayan artımsal eşdeğer deprem yükü yöntemi (itme analizi) sonuçları ve zaman tanım alanında doğrusal elastik olmayan yöntem sonuçları karşıllaştırılmıştır. Kullanılan yöntemler için en önemli farklılık, deprem isteminin tanımlanması ve büyüklüklerinin birbirlerinde farklı olmasıdır. 
Yapılan çalışmada zaman tanım alanında doğrusal elastik olmayan yöntem, sadece karşılaştırma için kullanıldı ğından dolayı sadece üç deprem kaydı ile gerçekleştirilmiştir. Şekil 3.5 'de bu üç deprem kaydı ve itme analizi neticesinde elde edilen en büyük göreli kat ötelemelerinin değişimi verilmiştir.

Binanın her iki doğrultusunda ve her üç deprem kaydı için taban kesme kuvveti ile tepe yerdeğiştirmesi çevrimleri Şekil 3.6 ve 3.7 'de verilmiştir.

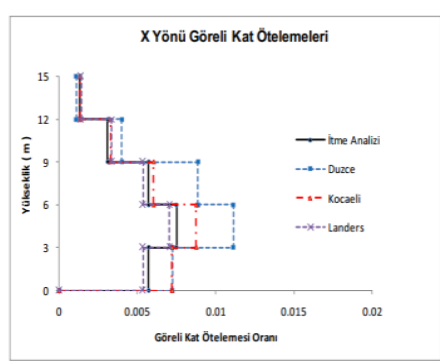

a)

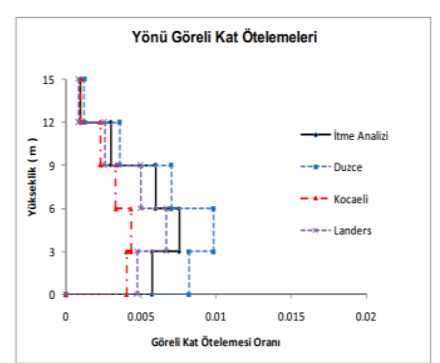

b)
Şekil 3.5. Sürtünme sönümleyiciler ile güçlendirilen binanın, doğrusal elastic olmayan artımsal eşdeğer deprem yükü yöntemi için elde edilen göreli kat ötelemeleri ile zaman tanım alanında doğrusal elastik olmayan analiz için elde edilen göreli kat ötelemelerinin karşılaştırılması, a) X doğrultusu, b) $Y$ doğrultusu

Şekil 3.8'de, binanın her iki yönü için tepe yerdeğiştirmesinin zamana bağlı değişimi verilmiştir. Ayrıca, itme analizi için elde edilen tepe yerdeğiştirme istemi ile bu değerler karşılaştırılmıştır.

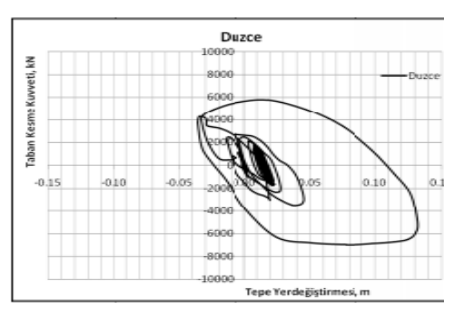

a)

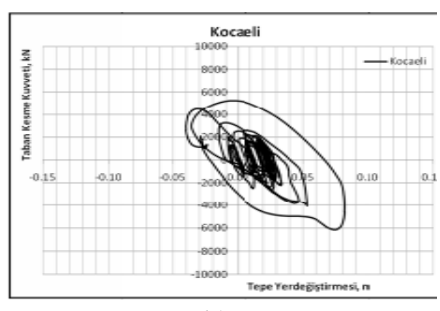

b)

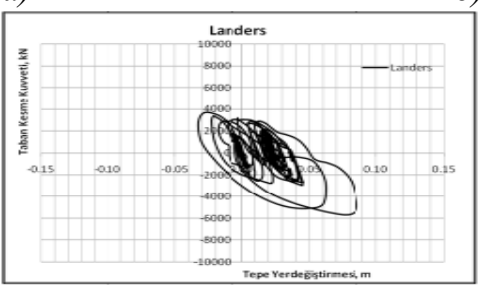

c)

Şekil 3.6. Sürtünme sönümleyiciler ile güçlendirilen binanın $X$ doğrultusunda taban kesme kuvveti - tepe yerdeğiştirmesi çevrimleri, a) Düzce Depremi, b) Kocaeli Depremi, c) Landers Depremi

Son olarak Şekil 3.9'da taban kesme kuvvetlerinin zamana bağlı değişimi, itme analizinin son adımında elde edilen taban kesme kuvveti istemi ile karşılaştırılmıştır. Her üç deprem kaydı için elde edilen sonuçların, itme analizinden elde edilen taban kesme kuvveti isteminden daha fazla olduğu görülmüştür.

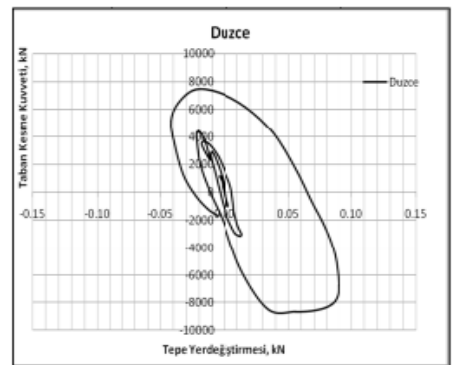

a)

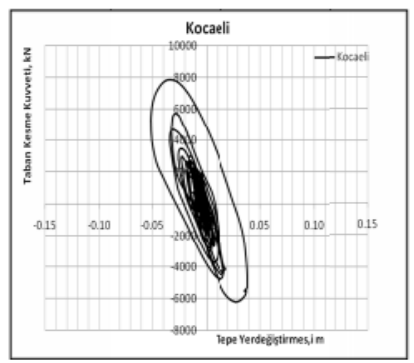

b)

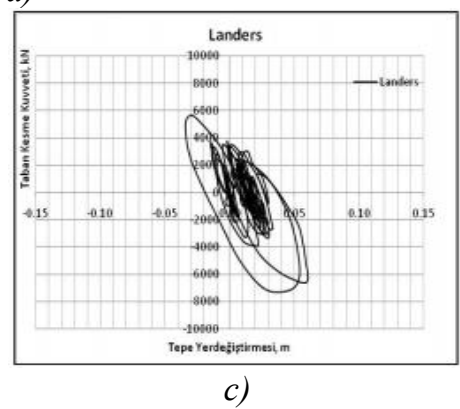

Şekil 3.7. Sürtünme sönümleyiciler ile güçlendirilen binanın Y doğrultusunda taban kesme kuvveti - tepe yerdeğiştirmesi çevrimleri, a) Düzce Depremi, b) Kocaeli Depremi, c) Landers Depremi

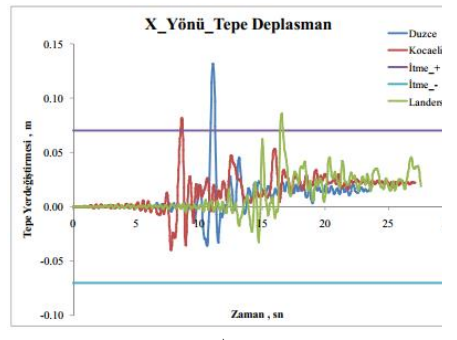

a)

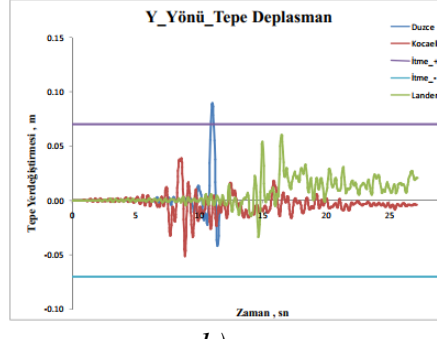

b)

Şekil 3.8. Sürtünme sönümleyiciler ile güçlendirilen binanın tepe yerdeğiştirmesinin zamana bağlı değişimi ile artımsal eşdeğer deprem yükü yöntemi ile elde edilen tepe deplasman talebinin karşılaştırılması, a) X doğrultusu, c) Y doğrultusu

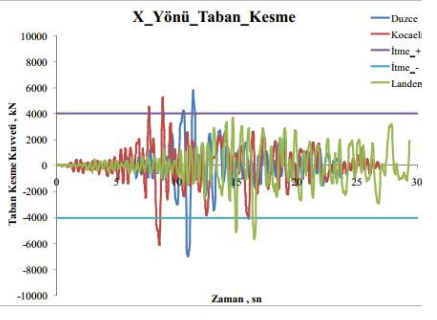

a)

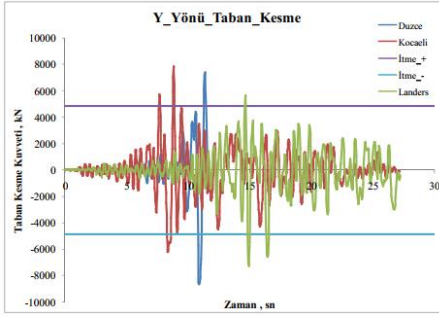

b)

Şekil 3.9. Sürtünme sönümleyiciler ile güçlendirilen taban kesme kuvvetinin zamana bă̆lı değişimi ile artımsal eşdeğer deprem yükü yöntemi ile son adımda elde edilen taban kesme kuvvetinin karşılaştırılması, a) X doğrultusu, c) Y doğrultusu

\section{Sonuçlar ve Öneriler}

$\mathrm{Bu}$ çalışma kapsamında deprem performansı yetersiz olan tipik bir kamu hastane binasının, geleneksel yöntem olarak betonarme perde duvarlar ile güçlendirilmesine ve modern yöntem olarak sürtünme sönümleyiciler ile güçlendirilmesine 937 
ilişkin, doğrusal olmayan itme analizleri kullanılarak elde edilen sonuçları karşılaştırılmıştır. Ayrıca mevcut bir binanın, sürtünmeli sönümleyiciler ile güçlendirme uygulanmasına ilişkin, artımsal eşdeğer deprem yükü yöntemi (itme analizleri) sonuçları ile zaman tanım tanım alanında analiz sonuçları kıyaslanmıştır.

Sürtünme esaslı sönümleyiciler, sisteme ilave sönüm, dayanım ve deformasyon kapasitesi sağlamaktadırlar. Sönümleyicileri mevcut binaya bağlayan çapraz elemanların rijitliği, mevcut binanın dinamik özelliklerini değiştirerek depremin yerdeğiştirme istemini azaltmakta, sürtünme ile elde edilen sönünmleme etkisiyle doğrusal olmayan davranış sayesinde, deprem enerjisinin kontrollü olarak tüketilmesi sağlanabilmektedir. Söz konusu elemanlar, sürtünme aktivasyon kuvveti kapasitelerine bağlı olarak sistemin yük kapasitesinin artmasını sağlamaktadırlar. Ayrıca, mevcut elemanlar üzerindeki hasar seviyeleri bu yöntemle azaltılarak, bina genelinde oluşan hasar kontrol altına alınmaktadır.

Sürtünme esaslı sönümleyiciler, özellikle mevcut kolonlar üzerinde kesme yükü istemlerini azaltarak, bu elemanlarda istenmeyen hasar durumlarının oluşması engellenmektedirler. Ancak günümüzdeki yapı stoğunun taşıyıcı sistem ve malzeme özelliklerindeki yetersizliklerinden dolay1, sönümleyicilerin yerleştirileceği çerçeve elemanlarına ilave bir müdahale söz konusu olmaktadır. $\mathrm{Bu}$ elemanlar lifli polimer malzemeler kullanılarak hızlı ve bina kullanımını sınırlı sürede aksatmak koşuluyla, kolaylıkla takviye edilebilirler.

Yapı deprem performansında, sürtünme esaslı sönümleyiciler ile güçlendirme sonucunda, betonarme perde eklenerek yapılan güçlendirmede olduğu gibi önemli ölçüde artış olduğu belirlenmiştir. Mevcut durumda göçme bölgesine ulaşan kolon hasarlarının, her iki yöntemle de sınırlı hasar durumuna çekilebildiği görülmüştür. Kiriş hasarları açısından her iki yöntemde de mevcut duruma göre iyileşme elde edilirken, perde duvar ilavesinde bu gelişimin daha fazla olduğu tespit edilmiştir. Sürtünme esaslı sönümleyicilerin aktivasyon kuvvetleri üzerinde yapılacak değişikliklerle aynı seviyede gelişimin elde edilebileceği ön görülmektedir.

Hem sürtünme esaslı sönümleyicilerle güçlendirmede hem de betonarme perde duvarlar ile yapılan güçlendirmede, kat yatay ötelemelerinin ve göreli kat ötelemelerinin, mevcut duruma göre önemli ölçüde sınırlandırıldığı belirlenmiştir. Sürtünme esaslı sönümleyicilerle yapılan güçlendirmede kat kesme kuvvetlerinde mevcut duruma göre çok küşük oranda bir artış görülürken, perde duvarlarla yapılan güçlendirmede kat kesme kuvvetlerinin önemli ölçüde arttığı tespit edilmiştir.

Sürtünme esaslı sönümleyiciler ile güçlendirilen binanın doğrusal olmayan dinamik analizlerinde kullanılan kayıtlar için elde edilen sonuçların ortalamasının, artımsal eşdeğer deprem yükü yönteminden elde edilen sonuçlar ile oldukça yakın değerde çıktığı görülmüştür. Bunun sebebi binanın planda ve düşey doğrultuda düzensizlik durumlarını içermemesi ve kullanılan sönümleyicilerin kat planında oldukça simetrik bir şekilde yerleştirilmesidir. Düzensizliğin bulunmadığı, az katlı binaların deprem performansının belirlenmesinde, doğrusal elastik olmayan artımsal eşdeğer deprem yükü yönteminin oldukça hızlı ve etkin bir yöntem olduğu görülmüştür. Ancak daha kesin sonuçlara ulaşmak için, özellikle yüksek binalar ve düzensizliğin bulunduğu binalar için zaman tanım alanında analiz yönteminin kullanılması gerekmektedir ki bu durum daha fazla veri ile doğrulanmalıdır. Buna göre sürtünme esaslı sönümleyiciler ile güçlendirilen ve düzenizlik durumu sınırlı az katlı yapıların deprem performansının belirlenmesinde, özellikle farklı yerleşimlerin kontrol edilmesi aşamasında, uzun zaman ve emek alan doğrusal olmayan dinamik analizler öncesinde, artımsal eşdeğer deprem yükü yönteminin kullanılmasının uygun olabileceği görülmüştür.

Mevcut bir binada betonarme perdeler ile güçlendirme yapılması durumunda, binanın oldukça uzun bir süre boyunca kullanılamaması, daha fazla noktada müdahale ihtiyacı, özellikle perdelerin yerleştirileceği noktalarda mevcut temel sisteminin büyük oranda iyileştirilmesi ihtiyacı ve bu durumun uygulamadaki zorluğu v.b birçok konu, imalat aşamasında karşılaşılan en önemli sorunlardır. Buna karşılık, sürtünme sönümleyici elemanlar ile güçlendirme için yalnızca sınırlı noktalarda mevcut dolgu duvarların kaldırılması ve sürtünme sönümleyici sistemlerin mevcut elemanlara bağlantısının sağlanması genellikle yeterlidir. Ayrıca bu durumda, çoğu zaman temel sisteminde sınırlı müdahaleye ihtiyaç duyulmaktadır. $\mathrm{Bu}$ gibi nedenlerle sürtünme sönümleyici sistemlerin kullanımında montaj hızı ve kolaylığı ile toplam maliyet açısından da avantaj sağlanmaktadır. Çalışmada elde edilen sonuçlar, yukarıda değinilen genel bilgilerle birlikte düşünüldüğünde, sürtünme esaslı sönümleyici kullanımının güçlendirme adına önemli ve avantajlı bir alternatif olduğu görülmüştür.

\section{Kaynakça}

Afet Bölgelerinde Yapılacak Yapılar Hakkında Yönetmelik, T.C. Imar ve Iskan Bakanlığg Deprem Araştırma Enstitüsü Başkanlığı, Ankara, Temmuz 1975.

Afet Bölgelerinde Yapılacak Yapılar Hakkında Yönetmelik, T.C. Bayındırlık ve İskan Bakanlı̆̆l, Ankara, Ekim 1997.

Aiken I., Passive Energy Dissipation - Hardware and Appliacations, Los Angeles County and SEAOSC Symposium on Passive Energy Dissipation Systems for New and Existing Buildings , Los Angeles U.S.A, 1996.

ASCE-SEI 41-06, Seismic Rehabilitation of Existing Buildings, American Society of Civil Engineers, U.S.A, 2008.

Asher J.W., Young R.P., Ewing R.D., Seismic isolation design of the San Bernardino Couty Medical Center replacement Project, Struct. Des. Tall Build., 9, 265-279.

Brown P., Aiken I. D., Jafarzadeh F. J., Seismic retrofit of the Wallace F.Benneth Federal Building, Modern steel construction, AISC, Chicago.

Chadwell C. B., Imbsen\&Associates (2002), XTRACT- Cross Section Analysis Software for Structural and Eartquake Engineering, http://www.imbsen.com/xtract.htm (Ziyaret Tarihi: 29 Temmuz 2013). 
Chopra A. K. , Dynamics of Structures - Theory and Applications to Earthquake Engineering, Prentice Hall, Englewood Cliffs, New Jersey, 1995.

Clark P. W, Aiken I. D, Tajirian. F, Kasai. K, Ko. E, Kimura. I, Design proceduresfor buildings incorporating hysteretic damping devices, Post-Smiert Conf. Seminaron Seismic Isolation, Passive Energy Dissipation and Active Control of Vibrations ofStructures, Cheju, South Korea, 1999.

Clough R. W., Penzien J., Dynamic of Structures, Third Edition, Computers and Structures, Inc. , Berkeley U.S.A. ,1995.

Deprem Bölgelerinde Yapılacak Binalar Hakkında Yönetmelik, 2007.

Duyguluer, M. F.,The history of seismic design code of Turkey, Bulletin of theInternational Institute of Seismology and Earthquake Engineering, 1997, 31, 177-92.

Düzel E., Düşeyde Rijitlik Düzensizliği Bulunan Çerçevelerin Sönüm Elemanları ile ve Çelik Çaprazlar ile Rehabilitasyonu, Yüksek Lisans Tezi, Niğde Üniversitesi, F. B. E., Niğde, 2012.

Fardis M., Seismic Design, Assessment and Retrofitting of Concrete Buildings, Springer Dordrecht Heidelberg Londan, New York, 2009

Fahjan Y. M., Türk Deprem Yönetmeliği Tasarım İvme Spekturumuna Uygun Gerçek Deprem Kayıtlarının Seçilmesi ve Ölçeklenmesi, İmo Teknik Dergi, 2008, 4423-444.

FEMA 356, Prestandart and Commentary for the Seismic Rehabilitation of Buildings, Federal Emergency Managament Agency ( FEMA), 2000.

FEMA 273, NEHRP Guidelines for the Seismic Rehabilitation of Buildings, Federal Emergency Managament Ag. ( FEMA), 1997.

FitzGerald T. F., Thalia Anagnos, Mary Goodson, and Theodore Zsutty (1989) Slotted Bolted Connections in Aseismic Design for Concentrically Braced Connections. Earthquake Spectra: May 1989, Vol. 5, No. 2, pp. 383-391.

Hilber H. M., Hughes T. J., Collocation, Dissipation and "Overshoot" for Time Integration Schemes in Structural Dynamics, Earthquake Engineering and Structural Dynamics, 1998, Vol.6, 99-117.

Housner G. W., Limit design of structures to resist earthquakes, Proc. 1st World Conf. on Earthquake Engineering, 1956, pp.5.1-5.13, Earthquake Engineering Research Center, Berkeley CA.

Pall A., Pall R. T., Performance-Based Design using Pall Friction Dampers - An economical design solution, 13th World Conference on Earthquake Engineering, Vancouver, Canada , August 1-6, 2004.

Pall, A. S., and Marsh, C. (1980). "Optimum Seismic Resistance of Large Panel Structures Using Limited Slip Bolted Joints." Proceedings of the Seventh WorldConference on Earthquake Engineering, Istanbul, Turkey, Vol. 4, pp. 177-184.

Soong T.T., Spencer B.F., Supplemental Energy Dissipation: state of the art and stateof the practice, Engineering Structures, 2002, 24, 243-259.

Soong T.T., Dargush G.F., Passive Energy Dissipation and Active Control, Editors : Chen Wai- Fah, Structural Engineering Handbook, CRC Press LLC, Part 27, 1999.

Soong T.T., Kelly J.M., Feetch D.A., Wood S.L., Hayes J.R., Lai M.L., Nielsen E.J.,Seismic Applications of Viscoelastic Dampers, NCEERS's Building Project, TaskNumber 902107, 91-5131, 92-5202, 93-5111.
Soong T.T., Constantinou M.C., Passive and active structural vibration control in civil engineering, Department of Civil Engineering State University of New York at Buffalo , New York 14260.

Symans M.D., Charney F.A., Whittaker A.S., Constantinou M.C., Kircher C.A., Johnson M.W., McNamara R.J., Energy dissipation systems for seismic applications: Current practice and recent developments, Journal of Structural Engineering, DOI: 10.1061/(ASCE)0733-9445(2008)134:1(3).

TS500, Betonarme Yapıların Tasarım ve Yapım Kurallarl, Türk Standard1, 2000, ICS91.080.40.

TS498, Yapı Elemanlarının Boyutlandırlmasinda Alınacak Yüklerin Hesap Değerleri, Türk Standardı, 1997, ICS 91.040.

Türkiye Bina Deprem Yönetmeliği. 18 Mart 2018 Tarih ve 30364 Sayılı Resmi Gazete. 2018 